\title{
A Farewell to the Iberian Spanish Macho? An Analysis of Masculinity in Spain. Conversations with Experts
}

Uma despedida do macho ibérico espanhol? Uma análise da masculinidade em Espanha. Conversas com especialistas

Un adieu au macho espagnol ibérique? Une analyse de la masculinité en Espagne.

changes avec des experts

Juan Antonio Rodríguez-del-Pino

\section{CpenEdition}

\section{Journals}

Electronic version

URL: http://journals.openedition.org/rccs/8398

DOI: $10.4000 /$ rccs. 8398

ISSN: 2182-7435

Publisher

Centro de Estudos Sociais da Universidade de Coimbra

Printed version

Date of publication: 1 May 2019

Number of pages: 5-24

ISSN: 0254-1106

\section{Electronic reference}

Juan Antonio Rodríguez-del-Pino, «A Farewell to the Iberian Spanish Macho? An Analysis of Masculinity in Spain. Conversations with Experts », Revista Crítica de Ciências Sociais [Online], 118 | 2019, Online since 26 April 2019, connection on 20 March 2020. URL : http://journals.openedition.org/ rccs/8398; DOl : https://doi.org/10.4000/rccs.8398 


\section{A Farewell to the Iberian Spanish Macho? An Analysis of Masculinity in Spain. Conversations with Experts}

The traditional model of masculinity in Spain (the so-called Spanish Macho) is heir to a long tradition of understanding how masculinity is framed as an omnipotent model assuming that "a man has license to do whatever he wants". This idealized behavioral pattern is slowly changing in Spain, as it accompanies the transformations in Spanish society. Certain public policies have provided momentum for a change in the way that the issue of gender in general and gender violence in particular are approached. A study carried out under the auspices of the University of Valencia between 2013 and 2015 interviewed experts and activists from an association of men seeking equality with women in an attempt to analyze the present situation and, above all, and to examine the future of masculinity in Spain as it relates to the gains made in favor of feminism. Using the opinions of several actors as a basis, certain questions emerge and the difficulties confronting this process are revealed: Is a rupture with traditional models possible? What is the present status of the coexistence between the most traditional and the most egalitarian approaches?

Keywords: gender equality; gender violence; masculinity; Spain.

\section{Introduction}

Connell explains hegemonic masculinity as "the configuration of the commonly accepted response to the problem of legitimacy of patriarchy, so that it guarantees (or is taken to ensure) the dominant position of men and the subordination of women" (Connell apud Valdés and Olavarria, 1997: 39). Research in the newly formed field of "Men's Studies" first emerged at universities in the United States in the 1970s. In Spain, a certain line of studies in this direction by Josep Vicent Marqués $(1982,1991)$ appeared in the 1980s. Although we cannot speak of a current as such, there are researchers who have analyzed this topic thoroughly. The trend toward interdisciplinary studies in the 1990s was consolidated by the works of Enrique Gil $(1997,2006,2008)$, Carlos Lomas $(2003,2008)$, Teresa Torns (2004) (on the 
relationship between economy, employment and gender), etc. Since the beginning of the new millennium, the number of studies has increased with the publication of works such as those by Fernando García-Selgas (2016), Paco Abril and Alfons Romero (2011), Luis Bonino on the "Hombres por la Igualdad" movement (2002, 2008, Oscar Guasch on the LGTB movement (2006, 2008, 2012), and Miguel Lorente on gender violence (2013, 2009, 2001), etc. However, one cannot - or should not - forget the importance of the men involved in the discourse on gender - and of their practices.

Despite the above, no academic research has been done to date on the subject of masculinity in Spain. It has enjoyed a certain popularity, due to the implementation of a plural and diverse set of experiences, practices, actions and interventions connected with couple's relationships and mainly related to gender violence (Lorente, 2001; Bonino, 2008; Caro and Fernández-Llébrez, 2011), as well as the institutional momentum given by public gender policies (Astelarra, 2005; Campillo, 2010; Pazos, 2010; Rodríguez, 2011).

The University is not unaware of the evolution occurring in the rest of Spanish society. The issue of gender, masculinity, and the relationship between men and equality is generally considered a minor issue, and thus it is not on the agenda. The topic of men and masculinity is approached in a tangential and secondary way, implying that studies on these issues are not promoted as a way of knowing and "recognizing" other people.

\section{Methodology}

The aim of the study ${ }^{1}$ was to obtain a thematic panorama representative of the current attitudes in academic circles through the eyes of those who have examined the subject of masculinity based on the research in Psychology by Juan Fernández, from the point of view of Sociology in the work of Antonio García, from the persepective of Political Science as in Fernando Fernández-Llebrez, and from the philologist Àngels Carabí, whose research is established firmly in the Social Sciences.

Interviews were also carried out with men from social movements who for years have been involved in diverse militant equality groups. We considered that the most appropriate approach to study this problem would be from the traditional analytic perspective of social anthropology, which also implied an evident methodological positioning. We also considered the current qualitative method as ideal for a study of these characteristics.

\footnotetext{
${ }^{1}$ Interviews done in the framework of an unpublished Doctoral thesis, entitled "The Psycho-Social Reconstruction of Masculinities. Unemployment and Cohabitation in the Home Environment", carried out by the author and presented to the University of Valencia, Spain, in 2015.
} 
Qualitative research is inductive; it develops concepts and conceptions that are based on the information obtained. Our interest was in understanding the social phenomenon from the point of view of those involved in it.

From the various theoretical interview models available, we opted for the Briggs-Wengraf model. For Valles (2005) this is a "more anthropological" approach that aims to capture the "real life context". There is a certain current of emotions and evaluations between interviewer and interviewee that are affected by a number of concurrent elements, namely those he calls socio-spatial and temporal circumstances - the venue, day, time, etc. - which influence and modify the contents. Experts, for example, are interviewed in their workplace whereas activists are interviewed in less formal surroundings (cafés, bars, meeting rooms) in a more casual and relaxed atmosphere. The pertinent features of the interaction are:

1. The scope of the interview. Even though we knew from the start what groups to address, on certain occasions some interviewees provided us with information to further examine relevant issues:

1.1. Enlarging the pool of interviewees. One interviewee can open the door to the next.

1.2. The interviews describe their personal relationships with the others.

2. The interaction viewed as a power relationship between the interviewer and the interviewee can change over the course of the interview. One starts off with a fixed script of questions, but in practice these are continually modified as the interview progresses and the interviewee develops different viewpoints.

It was difficult to decide on the number of people to be interviewed. We did not look for statistical representation, but rather an understanding of the viewpoints. As the most important consideration was the content of the information, we applied the saturation principle. In the end seven interviews were performed, all with men, except for one female researcher from the University of Barcelona.

Scripts were drawn up on both general and specific subjects on which information was to be obtained. The objective was to get to know the status of the question on a theoretical level, the status of the research that had been carried out and the research being carried out, and also to ascertain the opinion of the man in the street, how questions such as equality, new forms of masculinity, etc. were viewed on an everyday social level.

The structure of the topics was planned progressively, from the most general, of lesser interest, because they were the furthest from the interviewee, to the most specific, and therefore nearest to the person in question. 


\section{Being a Man in Spain. From the Individual to the Collective}

Masculinity in $20^{\text {th }}$ century Spain, very much like the rest of Europe, was marked by the violent images of war. On the Iberian Peninsula these appeared during the Civil War, and the regime that emerged thereafter. Franco's discourse structured the stereotyped models of "being a man" and "being a woman" in a very essentialist way, establishing the sexual difference on a national-Catholic religious foundation that justified masculine domination and female subordination as something natural and incontestable (Vicent, 2006). This model was prevalent throughout the remainder of the $20^{\text {th }}$ century and into the $21^{\text {st }}$. To inquire about this and other topics, we interviewed both university experts and activists involved in "Hombres por la Igualdad".

Antonio Garcia of the University Complutense of Madrid (hereafter UCM), denies the existence of a "being man" in general although he admits to the need in society for a gender-sexual reaffirmation during adolescence, since it is "approximately from 15 to 18 that the whole model of manliness associated with the new industrialized and democratic society, inherited from the times of the dictatorship, is reconstructed; and this is something which is very present today".

This points to a key element within the adopted male role, and to the fact that it acquires meaning in relation to others (with other men and women). The masculine is affirmed by the exercise of power (Bourdieu, 1998) as a sample of autonomy. And so, Garcia continues: "What ends up being a man is always the result of a relationship of power in which others have to recognize me".

Àngels Carabí, an expert the philology of masculinity, from the University of Barcelona (hereafter UB), introduces the question of social construction (Berger and Luckmann, 1979) to explain the dichotomous differentiation between man and woman.

Spanish society is very structured with many gender values, and masculinity implies a series of cultural values which indicate how a man should be, just as the feminine values dictate how a woman should behave. As Simone de Beauvoir once said: "One is not born, but rather becomes, a woman" (1949: 13); in the same way, one is not born, but rather becomes, a man.

This dichotomous structure, which creates ideal social behavior models, fails because no one, male or female, can adopt the whole, pure model. We never seem to look like the model. This functions as an unreachable element, as an idealized sample of what we should seek. Fernando Fernández-Llebrez of the University of Granada (hereafter UGR) believes, following Mosse (1996), that the configuration of a male stereotype which 
is constructed as an ideal model is a failure. It is the configuration of a stereotype as a normative ideal that is projected onto the whole of society. Juan Manuel Torres of the "STOP Machismo" and "Foro de hombres" movements (hereafter STOP Machismo) points out the need for continuous questioning by men, as individuals in perpetual relationship with others, as indicated by Kimmel when he states that Man "is historically built [...] is a socially constructed being" (Kimmel apud Valdés and Olavarría, 1997: 23).

Despite the existence of conditioning stereotypes, we humans are not really as mediated as it may seem; we have a certain degree of maneuverability within the context. Maria Luisa Tarrés points out that it is possible that individuals despite all the circumstances, be they men or women, or both together, can ultimately control their situation in the context, as they are "reflexive subjects that, despite being conditioned by the logic of power relationships, they also manage them, thus influencing their reproduction or the production of alternative codes of relationships" (Tarrés, 2012:380).

\section{Masculinities or New Masculinities? An Open Debate}

The definitions of masculinities have very similar nuances, as acknowledged by Antonio García (UCM), who agrees with the postulates of the also critical sociologist Jeff Hearn (1998), in so far as the polysemy of the concept is concerned:

We must realize that there is not a single masculinity: masculinity is a multiple fact and, therefore, we must talk about masculinities. There are different ways to embody an identity position, to own it, to readapt it, to construct it [...] When we face the question of what is it to be a man, what we are going to find are different reconstructions of that model, and that is where the theoretical difference goes: keeping on thinking about a single model of masculinity is a trick. Men are expressing their masculinity in different contexts. In each specific context, we update, pull, and turn these models into different ones.

Fernando Fernández-Llebrez (UGR) recapitulates from a political and historical point of view:

I cannot talk about what it is to be a man, if I do not understand what it is to be a woman. What we have are different ways of being a woman. Therefore, you cannot give a single answer to what it is to be a man, it is a mistake. And it is advisable to put it into context in order to understand the discursive meaning of the context of what we speak about. If we look at men and women in different times in history, and analyze them in a synchronous way, that is, comparing different concepts at 
different times, we find several concepts of masculinities. Of course, no studies have been done on all this plurality.

\section{Egalitarian Men: An Entelechy?}

What has been called the new masculinities is undergoing a rethinking. As Erik Pescador, from the Center for Gender and Masculinities Studies (hereafter CEGM) points out, using certain more or less recent theories, he aims on the one hand to diversify discourses on masculinity (Waisblat and Sáenz, 2011) and on the other, to generate possibilities of choice and change (Fernández, 2011) by generating the possibility for men to choose their own form of masculine expression beyond the rituals and structures of traditional male behavior. So the new masculinities are different ways of facing identity, and that identity is a powerful referent of oneself, rather than the social representation of a structured, destructive patriarchal model. This may not be novel, yet what is new at present is a stronger social conscience. In fact, in the Spanish State studies dealing with new masculinities have been carried out for between 10 and 15 years. However, there is a clear need to persevere in this field, especially from the approach to the issue of violence.

In this way, the new masculinities in Spain, for Jesus Gassent of the Men's Central Space (hereafter MCS), must serve to break the patriarchal structure of unequal relations: "With the economic crisis they will have to readapt those relationships so that they no longer have a hierarchical structure, and instead start having a structure of equality and equalization... this is the challenge we face now".

In any case, bearing in mind that "so far, men do not even have the awareness that this change is necessary and possible" (Gabarró, 2008: 105), yet being mindful of the existence of leading entities and associations in this area, some of them were invited to define which characteristics, those so-called egalitarian men have or should have, ${ }^{2}$ and the response was, to say the least, diverse. A more positive attitude was shown by Juan Manuel Torres (STOP Machismo), who believes in a person who observes the injustice of society and aims to change it, renouncing the privileges with which he has been endowed by the mere fact of being born a man: "He believes that society is unjust. He fights deep inside himself, in his personal behavior, and then tries to pass the result on to others [...]. You want to change it inwardly

\footnotetext{
${ }^{2}$ It is interesting to note Gabarró's assertion when he defines an egalitarian man as one who "must incorporate an empathetic gaze that leads him to relate equally to women and to any otherness (racial, cultural, religious, sexual orientation, etc.). He must have incorporated those differences as personal enrichments and not as marks indicating inferior social strata” (Gabarró, 2008: 105).
} 
and you struggle in your daily life to change it. You want to renounce the privilege you have. You have to change it gradually, day after day".

From less optimistic, yet maybe more realistic, approaches, Erik Pescador (CEGM) denies the existence of a true model of "egalitarian man":

[...] I have yet to meet an egalitarian man. I do not think he even exists. I have been working on this for 17 years, and many of the people who work with me in this area continue to find new spaces of microviolence, micro-male chauvinism, not as evident as in other cases, but those traditional forms of power expressed in a very subtle way still exist.

What is said by Pescador contradicts the most recent theories on this topic (Szil, 2000; Montesinos, 2004; Guasch, 2006; Tobío, 2012, etc.) echoed by Jesus Gassent (MCS) when he indicates that the key is to endow Man with what is traditionally denied: emotions. "We men can go down from the intellect to the emotional. That is, to the moment in which we can give words to an emotion. As soon as we can put words to what we feel, to what we think, we open the possibility of communicating and relating in another way. That is the key".

Juan Fernández (UCM) points out the conceptual and binomial differentiation between women and men from the perspective of the changes in the psychological view of the subject (mentioning earlier article Fernández, 2001), when indicating that masculinity and femininity are elements independent of sexual gender.

\section{Equality in Spain}

Àngels Carabí (UB) highlights the prism of the current social context in Spanish society: "We are going through a very important drawback. We are living in a period of great disadvantages in the different levels of Spanish society, economy, politics, ideology [...]".

Ester Barberá asserts that stereotypes (in this case, gender), insofar as they are "simplified schemes of knowledge, have a clear adaptive function, namely facilitating the information of the environment and preparing us to face it with a certain knowledge" (Barberá apud Barberá and Martínez, 2004: 74), which implies flexibility and adaptation to changes. Faced with these positions, Juan Fernández (UCM) highlights the difficulties that exist in changing stereotypes and beliefs and also positions himself against it: "No stereotypes, beliefs take a long time to be modified, roles take even longer to be modified. There is no society, none, not even Nordic societies. In fact, regarding wages, there is no society that pays equal wages for equal work, it is always asymmetric". 
We observe two positions established in the contemporary Spanish society. The first is unwavering and categorically denies that our society promotes equality. Thus speaks Juan Manuel Torres (STOP Machismo), who observes the importance of educational institutions as instruments of change, and states that:

The family and the school are places to correct, practice and children must change. We cannot change society either from a discourse, or from politics: it has to be education, from day to day routines. If children see in their environment how we interrelate, and when they go to school they keep on watching the same thing happening, those children will change. But that does not happen.

Jesus Gassent (MCS) raises his voice in a more negative tone. He also explains the need for the environment to change, but nowadays that environment is not favorable for these issues, ${ }^{3}$ since

it is an environment contrary to the egalitarian, a competitive environment and, traditionally, within a competitive environment women had every chance of losing. Advances have been claimed but this has simply meant that we have moved a little bit. In fact, with the socialist government, ${ }^{4}$ equality policies apparently once seemed to be on the point of changing us now there are no equality policies.

Yet with slight differences, the position of Spanish society shows the progress - more or less consolidated - in egalitarian processes. Erik Pescador (CEGM) points out that although society is generally in favor of equality, men are afraid of losing power in an uncontrolled space. And Spanish society in the process of equality is an uncontrolled space since, on the one hand women are making profound changes to their ways of proceeding, ${ }^{5}$ and on the other, there are men who do not act in the way men have traditionally acted:

\footnotetext{
${ }^{3}$ There are apocalyptic analysts who view society as a sick organism, mortally wounded and with solutions too complex to achieve their recovery. Among those we find Zygmunt Bauman (2003), Gilles Lipovetsky (1983), and in Spain, Vicente Verdú (2003), to name a few.

${ }^{4}$ When the PSOE (Spanish Socialist Workers' Party) of President José Luis Rodríguez Zapatero was in power (2004-2011).

5 "The woman was the great unknown of mankind and no one saw the need to question man. Masculinity seemed obvious: clear, natural, and contrary to femininity. In the last three decades, this old-time evidence has been shattered. Women in their urge to redefine themselves have forced men to do the same" (Badinter, 1993: 14).
} 
On the subject of equality, Spanish society is deeply polarized. One part profoundly questions their daily lives, with men who are reluctant to change, and even violently against doing so. Ángeles Álvarez, in a loud voice, uttered the magical phrase: 'women do not want the power of men, they just want their part of power and nothing more. However, men are afraid of turning the tables'.

Antonio García (UCM) affirms that, on the legal and also formal level, equality is fostered, since the principle of equality is at the heart of current social values:

It has become a driving principle, but we see that it is being continuously perverted, and our politicians pervert policies. Does our Spanish society foster equality? I do not think we live in a society that is getting more egalitarian. No, here we are going to turn around every year, but we continue the same or maybe a little worse.

Fernando Fernández-Llebrez (UGR) considers that society is more egalitarian than the institutions governing it. This coincides with what Berger and Luckmann (1979: 111) put forward when they pointed to the conservatism of institutions as a need for legitimacy "by assigning normative dignity to their practical imperatives":

Formally, I believe that there have been many advances, but I cannot say the same about the values that are being put on the table by the institutions. I want to think that people, the average citizen, are much more sensible and able to see that this identification is an outrage. In this case, I trust society more; I believe that in society there is more power of equality than there is in our institutions right now. I do not say that there is more equality in society: I say that there is more potentiality $[\ldots]$.

\section{New Models of Man-Woman Relationship in Everyday Life?}

In Spanish society the term "feminism" suffers from such continuous harassment to the point of being repudiated by women themselves. Antonio García (UCM) notes that:

What is feminism and what does it mean? If you say to a man: 'be a feminist', he will answer: 'no, no, no feminazi'. I think that, as a society, we have neglected something that was fundamental: in order to be more egalitarian we have to be more equal, and we have to somehow invest, rethink ourselves, and we must pay attention to what all these women have said. And I think there is a problem, a difficulty on that plane is how we make men and many women understand again 
what is behind feminism, make them understand again why there is work to be done and what is being asked for. ${ }^{6}$

Gender relationships are established through ritualized formulas where, as Goffman points out, "one often finds that someone is given the right to direct and control the progress of dramatic action" (Goffman, 1978: 101). In the case of gender, this leading role has been historically attributed to man. Antonio García (UCM) continues:

How to break this trend? I can appeal to the responsibility of people for them to be more egalitarian, but I think that as people who take part in the social processes, we would be wrong if we thought we are going to change that through the relational. We have to change a lot of guidelines, a lot of ways of doing things... and I think in these proceedings it is very complicated, yet it is where you could really do something. So I do not think it is a lack of interest. Is there a lack of interest? For sure there is; is there a certain amount of ignorance? For sure there is; but I also think there is a feeling of security that everyone is afraid to lose ${ }^{7}$ so how can that change be made? That is the difficulty. That is why I think that many times the fundamental factor is being with someone, either in a group or with a partner, to treat you in a different way.

A recurring theme among all the experts interviewed is the approach of the "reluctance to change" on the part of men in relation to equality. Regarding groups of men, there is an underlying debate - with a certain amount of criticism of these groups - that end up having a self-indulging and victimized image of the "perfidious" feminists. Fernández (UCM) argues that these groups "are seeking to beat the deteriorated image of man or else to show the world that not all men are male chauvinists, that there are indeed men in favor of equality" (Fernández, 2014: 48). He introduces the question of whether men can be feminists or if that is only possible among women:

In fact, in the same debate about the concept of how we define men, lies the essence of the debate, that is, why do we not call ourselves feminists? Why do we call ourselves pro-feminists? Or why are there so many terms for self-designation? And there

\footnotetext{
${ }^{6}$ On the counter-positioning that patriarchal society has vindicated against feminism, see Varela (2008): Feminismo para principiantes (Feminism for Beginners), Cobo (2011): Hacia una nueva política sexual (Towards a New Sexual Policy), Valcárcel, (2008): Feminismo en el mundo global (Feminism in the Global World).

7 Once again the male fear of losing their status: "men feel threatened" (Segal apud Carabí and Armengol, 2008: 173) and this usually implies a return to masculine exaltation when it is put into question. It is discovered when it feels it is being attacked, an otherwise androcentric point of view is considered as neutral (Bourdieu, 1998: 22).
} 
we enter into a more complex debate of a philosophical nature that implies a bit of how identity is experienced. I will set an example outside gender: "if you are not black, can you be part of the US anti-racist movement? Yes, probably, but maybe not being black does not allow you to experience the discrimination that black people have felt. In cases of gender issues, if you are not a woman, can you call yourself a feminist? It is a bit complicated, I insist, as we are in the middle of a process of transformation, of transit.

Luis Bonino (2002: 23) affirms the need to create spaces where men are taught to "delegitimize the monopolistic use of 'masculine' rights, which men are reluctant to give up, as well as creating and developing desires to change in order to foster equality".

Some groups of feminist men warn of the need for forums exclusively for men. This is, perhaps, a somewhat drastic action that can be misinterpreted and manipulated but neither can it be categorically rejected, since it is necessary to create places for reflection among men.

The question here would be preceptive: are there common places for reflection between men and women? And here Goffman (1978: 30) is enlightening when he states that: "Each one of us always plays a role before others $[. .$.$] it is there that we get to know ourselves". Taking into account$ that men in Spain are currently be placed on a long panorama of opinions on feminism, Antonio García (UCM) points out the various ways:

There are women who accept that we call ourselves feminists. But other women do not accept that due to historical tradition. It is here that the essence of all this debate dwells, with a very complicated and well-kept background with the men movement. I also wanted to make this clear, the non-acceptance by feminism of those men movements by using the post-male chauvinist discourses, as Lorente would say. Certain men feel attacked by feminism or equality because obviously 'I rethink my masculine identity but from essentialist positions'.

Àngels Carabí (UB) also cannot help seeing how some young women exhibit resistance to change, and models of men are sought that do not turn out to be at all egalitarian:

It is hard because when you talk to teenage girls, there is a study by the Autònoma (university in Barcelona) of 'What kind of guy do you like?' And the answer is 'the tough one, the one who mistreats me... and then, when I am 30 and willing to get married... I will look for another type... a more conversational one'. 
Fernando Fernández-Llebrez (UGR) draws a conclusion by noting various needs, namely, on the one hand, the need for identity changes based on new discourses of a higher egalitarian range, and on the other, changes in feminist discourses implicating men more in an "ally" role, instead of exclusively as the "enemy":

For this change to occur, we need two things: a change in men, with a process of discussion and debate. Taking equality seriously means a change in egalitarian values within the individual freedom inherent in every human being. We have freedom, deep equality, and caring for other human beings. And there we have to identify more men than women; these are values for everyday life, the first fundamental change to take place.

As a second change, a change in feminist discourse is desirable if we do not want to end up pronouncing the word 'feminist' and scare people away. We cannot build a feminism as aggressive as the one already existing. We need a kinder one, so that I can perceive it as a man... Men and women are not enemies, what separates us are those situations of inequality and injustice, and it is against this that we must fight, not against the 'man' label.

But, as Juanma Torres (STOP Machismo) points out the economic crisis (which began in Spain around 2008) has affected equality with a clear drawback in public policies on equality: "since they announced that they were doing away with the Ministry of Equality... from then on everything has collapsed, there is no help, there is nothing for men, women, or anything...”.

Citing the economic crisis as an excuse, there have been cuts in public policy funding in issues that have traditionally been seen as "minor" and that, in addition, could have implications for society in general by empowering citizens and enabling social change. For that reason, Erik Pescador (CEGM) bluntly states that: "the crisis has been a perfect excuse to paralyze the processes of radical change that implied a change in the field of gender, in the field of equality".

Although the reallocation of roles between men and women depends to a large extent on how domestic relations have been addressed before the crisis, however, Erik Pescador (CEGM) also considers that these changes in the family environment may cause unforeseen consequences:

It has been useful, so that many men return to the house and understand that there are spaces that have been lost during all these years. [...] More and more men have returned to the domestic space, have met their children, their partners, their daily lives... and if they have been able to get over losing their jobs as an identity issue, 
and have managed to relocate themselves in that new domestic space while their wives work... all of a sudden they have realized all that necessary and enriching space that is the couple's space of homecare and raising children.

The slow process of change was also observed by Paco Abril and Alfons Romero (2011:2) "Some changes have occurred basically in the cultural and ideological sphere, while changes in the areas of material inequality (time actually devoted to household chores or child care, for example) are far smaller. We are therefore faced with a more egalitarian society in terms of values, but still very unequal in terms of real practices". Fernández-Llebrez (UGR) picks up this idea:

Only five percent of men stand for equality, but they set a series of conditions, namely their ideology, which they are projecting on society. Many more men stand for the potential equality in our society than that five percent of what is usually spoken in all the speeches... Reality has not been studied, if you focus on real data, men of today are far more sensitive. Are they egalitarian? No, they are not, but they are more sensitive and for them to reach equality you have to get to know them and work with them as equals, and that is something that is not being done...

We consider that although there is unanimity in contemporary Spanish society, this does not promote universal equality; it is also true that certain nuances arise. For this reason we agree with Juan Fernández (UCM) on his perspective from the sphere of psychology, which suggests the need to set a time to change some deeply rooted beliefs and stereotypes, which make this process a longer one, regardless of the policies that are adopted, and in this he agrees with the theorists who observe the long processes of change. ${ }^{8}$

Also, from some point of view the answers on the equality are more specific, and thus the responsibility for promoting these issues falls to educational institutions. Basically other perspectives state that it depends on economic and political factors, but ones which are not interested in the development of egalitarian positions. We believe that limiting positions to a single factor is an overly reductionist approach. A problem as complex as equality requires a multi-causal analysis, and therefore the alternatives that must be provided will also be of various kinds. We understand that exclusively political-legislative responses (through laws and decrees) do not resolve the commitment to equality. In this sense, we propose that a great

${ }_{8}^{8}$ Difficulties in changing relationships between women and men (Badinter, 1993; Gutmann, 1998; Jociles, 2001; Lomas, 2003; Abril and Romero, 2011). 
State Pact should be carried out in which large communication organizations, political parties, and the associative movement in general (and religious associations in particular) would combine their efforts to aggressively promote holistic proceedings.

We therefore observe a diversity of positions among the people interviewed, if not directly antagonistic positions. We start with the argument of Antonio García (UCM), who indicates that, in fact, although Spanish society legally promotes equality, equality is not always accepted in certain sectors of society and we end up with the perspective of Fernando Fernández-Llebrez (UGR) who defines society as more equal than the institutions (cultural policies, etc.) that represent it.

We can infer, therefore, that on a daily, domestic level, while "the symbolic importance of the male breadwinner and female housewife model continues" (Borràs et al., 2012: 420) we can observe a certain evolution if we look back, say, 20 years, to an evolution that the new generations have assumed. Following this plot line, we must recognize two issues: first, the fact that the term "feminism" is currently and permanently being reviled by more conservative-reactionary positions in the mass media (among other scenarios), which is of no help, and second, the fact that men are extremely resistant to the concept of advancement in terms of equality, which is equally problematic. Although many women, of these new generations, unwilling to give up in the advanced.

One possible solution would be men seeking their own spaces for reflection, where they can understand and rethink their identity as individuals (individually and/or collectively). This process would promote co-responsibility and greater active involvement in the search for effective equality between women and men, vilifying the role of the aggressor.

\section{Discussion}

Certain subjects can be extracted from the information obtained, as subjects of reflection:

- Traditionally, the term "being a man" has been considered in relation to one's way of relating to others, from power positioning, inequality and authority, with the other party.

- This expression is given more and more importance as masculine and feminine identities are being constructed, especially in adolescence.

- The "being a man" model was built with only one dimension, considered as a normative model for social action. In Spain, it arose from a model based on the premises of the Falangist movement, in support of the Franco dictatorship in combination with certain fundamental family 
values preached by the Spanish Episcopal Conference. This set of ideas had ramifications that still exist today, but has turned out to be somewhat reductionist, since now it seems there are no men that totally comply with these specific regulatory characteristics of "being a man".

- On the other hand, the social (and psychological) reality shows that men as well as women do not all possess the same profile. The Spanish reality shows us how so many different profiles exist (under tension) as there are cultural types.

- The so-called new masculinities, multiple masculinities, or simply masculinities, contribute a diversity of opinions in Spain. They allow men to choose how they wish to express their masculinity, outside the traditional rituals and behavioral structures.

- However, the new more plural masculine classification may reach the point of establishing behavioral models that question reality, the existing relationships, and make possible the end of relationships based solely on essentialist social systems.

- It is clear that considering masculinity as a single viable model is simply serving an interest. Reality shows us that men express their masculinity in different contexts and in different ways. There are as many types of masculinity as there are societies and cultures within each society.

- In spite of the new possibilities offered by the kaleidoscope of masculinities, it is difficult to poinpoint exactly what an "egalitarian man" is. Observations are made from postures that deny the existence of egalitarian men: "I have yet to meet an egalitarian man" (Erik Pescador, CEGM); even those who have detected characteristics that are being transformed, based on the emotional, on the expression "Put your emotions into words".

- The questioning by one's self of a masculine position is a long and costly process that springs from one's personal questioning and from the place that each one occupies (or may occupy) in society.

\section{Conclusions}

In the current implementation and planning of state policies in Spain, we see that there is little interest among the official organizations regarding effective equality between women and men despite the existing regulations. In this regard, answers with little or no nuances are being provided by government or official entities, as if dealing with a petty and unimportant topic. This represents a somewhat lax response from the State, one lacking a genuine egalitarian attitude. When society, organizations and men in general are called to adopt a position or an opinion on issues such as transsexuality, 
androgyny or multiple masculinities, it is then that honest opinions emerge without a mask. In general, a contemptuous and sometimes violent response could be the result of the natural discomfort that assails us when we are confronted with someone who does not fit the prototypical characteristics learned during our childhood, according to which, that is the way the "man" is, and that is the way the "woman" is and beyond those landmarks, everything else is anomalous. This almost atavistic fear comes from the unknown.

The multiple forms of "being a man" nowadays cause a certain tension in the environment. We have investigated the "white man" without considering other more anthropological factors, such as the ethnic factor. The most patriarchal forms tend to be reluctant to change and, although each of these forms fits a different societal ecosystem, the Spanish western urban ecosystem demands a system better adapted to a context model of man, for whom the physical no longer has the value it once had. The emotional factor takes on increasing meaning as a relational element. In general, women have been better able to adapt to the changing social conditions. In any case, men are now beginning to show other ways of interacting. This can lead to some kind of movement toward a new and unknown context. In the same way, it implies that men are now more puzzled although they may still respond with violence towards what they consider their competitors in situations of loss (of status, of location in space and in time...). These positions are obsolete, since the man does not realize that the woman is the spark that triggers the change. Women have changed because the world changes and men must also change to adapt to the new circumstances.

In Spain, some male discourses support the need for equality, despite reluctance, fears and uncertainties, etc. However, change happens through reflection on the role of the man in a changing society and the practical implications involved. Both have to be rethought from a critical perspective, de-legitimizing the traditional hegemonic positions, which are beginning to be perceived as obsolete.

Edited by Scott M. Culp

\section{References}

Abril, Paco; Romero, Alfons (2011), "El papel de los hombres en la igualdad de género: cambios, perspectivas y transiciones”. Comunication presented at the Congress Iberoamericano de Masculinidad y Equidad. Barcelona. Accessed on 14.10.2016, at http://www.elpuertodesantamaria.es/pub/igualdad/ago12/papel-hombres.pdf.

Astelarra, Judith (2005), Veinte años de políticas de igualdad. Valencia: Ediciones Cátedra. 
Badinter, Elisabeth (1993), XY, La identidad masculina. Madrid: Alianza Editorial. Barberá, Ester; Martínez, Isabel (eds.) (2004), Psicología y género. Madrid: Prentice Hall. Bauman, Zygmunt (2003), Liquid Love: On the Frailty of Human Bonds. Cambridge: Polity Press.

Berger, Thomas; Luckmann, Peter (1979), The Social Construction of Reality. Middlesex: Penguin Books Ltd.

Bonino, Luis (2002), "Las microviolencias y sus efectos: claves para su detección.”, in C. Ruiz-Jarabo; P. Blanco (eds.), La violencia contra las mujeres: prevención y detección. Madrid: Ediciones Díaz de Santos, 83-102.

Bonino, Luis (2008), Hombres y violencia de género. Más allá de los maltratadores y de los factores de riesgo. Madrid: Ministerio de Trabajo e inmigración.

Borràs, Vicent; Moreno, Sara; Castelló, Laia; Grau, Anna (2012), "Male Hegemony in Decline? Reflections on the Spanish Case”, Men \& Masculinities, 15(4), 406-423.

Bourdieu, Pierre (1998), La domination masculine. Paris: Éditions du Seuil.

Campillo, Inés (2010), "Políticas de conciliación de la vida laboral y familiar en los regímenes de bienestar mediterráneos: los casos de Italia y España”, Política y Sociedad, 47(1), 189-213.

Carabí, Àngels; Armengol, Josep M. (eds.) (2008), La masculinidad a debate. Barcelona: Icaria.

Caro, María Antonia; Fernández-Llébrez, Fernando (2011), Buenos tratos: prevención de la violencia machista. Madrid: Talasa Ediciones.

Cobo, Rosa (2011), Hacia una nueva política sexual. Madrid: Libros de la catarata.

Connell, R. W. (1995), Masculinities. Cambridge: Polity Press.

De Beauvoir, Simone (1949), Le Deuxième Sexe, vol. 1-2. Paris: Éditions Gallimard.

Fernández, Melissa (2014), "Tendencias discursivas en el activismo de varones profeministas en México: algunas provocaciones a propósito del 'cambio' en los hombres”, Conexoes Psi, 2(1), 31-56.

Fernández, Juan (2001), "Research Trends in Spanish Psychology (1989-1998)", The Spanish Journal of Psychology, 4(2), 103-110.

Fernández, Juan (2011), "Un siglo de investigaciones sobre masculinidad y feminidad: una revisión crítica”, Revista Psicothema, 23(2), 167-172.

Gabarró, Daniel (2008), Transformar a los hombres: un reto social. Accessed on 11.09.2016, at https://danielgabarro.com/crecimiento-personal/descargar-libro-transformara-los-hombres-un-reto-social/.

Gil, Enrique (1997), El nuevo sexo débil. Los dilemas del varón posmoderno. Madrid: Editorial Temas de hoy.

Gil, Enrique (2006), Máscaras masculinas. Héroes, patriarcas y monstruos. Barcelona: Editorial Anagrama.

Gil, Enrique (2008), "Representaciones sociales de la masculinidad y la feminidad", Anuario de sexología, 10, 125-134. 
García-Selgas, Fernando J. (2016), "Redoing Gender Relations in Trasnational Lives: Ecuadorian and Senegalese Migrants in Spain”, Men \& Masculinities, 19(5), 439-459. Goffman, Erwin (1978), The Presentation of Self in Everyday Life. Harmondsworth: Penguin Books Ltd.

Guasch Oscar (2006), Héroes, cientificos, beterosexuales y gays. Barcelona: Edicions Bellaterra.

Guasch, Oscar (2008), "Los varones en perspectiva de género. Teorías y experiencias de discriminación", Revista Asparkía, 19, 29-38.

Guasch, Oscar (ed.) (2012), Vidas de hombre(s). Barcelona: Edicions Bellaterra.

Gutmann, Matthew C. (1998), "Traficando con hombres: la antropología de la masculinidad”, Revista de Estudios de Género. La ventana, 8, 47-99.

Hearn, Jeff (1998), “Theorizing Men and Men's Theorizing: Varieties of Discursive Practices in Men's Theorizing of Men", Theory and Society, 27, 781-816.

Jociles, María I. (2001), "El estudio sobre las masculinidades. Panorámica general”, Gazeta de Antropologia, 17(27), 1-14.

Lipovestky, Gilles (1983), L'ère du vide: Essais sur l'individualisme contemporaine. Paris: Éditions Gallimard.

Lomas, Carlos (2003), ¿Todos los hombres son iguales?: Identidades masculinas y cambios sociales. Barcelona: Ediciones Paidós.

Lomas, Carlos (2008), "La Dictadura del patriarcado y la insurgencia masculina (menos 'hombres de verdad' y más humanos)”, Revista la Manzana, III(6), 1-24.

Lorente, Miguel (2001), Mi marido me pega lo normal. Barcelona: Ares y Mares.

Lorente, Miguel (2009), Los nuevos hombres nuevos. Barcelona: Editorial Destino.

Lorente, Miguel (2013), "Posmachismo (I)”, El País press, 22 May. Accessed on 17.10.2016, at http://blogs.elpais.com/autopsia/2013/05/el-posmachismo-i.html.

Marqués, Josep Vicent (1982), No es natural: para una sociología de la vida cotidiana. Barcelona: Anagrama.

Marqués, Josep Vicent (1991), Curso elemental para varones sensibles y machistas recuperables. Madrid: Editorial Temas de hoy.

Montesinos, Rafael (2004), Las rutas de la masculinidad. Barcelona: Editorial Gedisa.

Mosse, George L. (1996), The Image of Man: The Creation of Modern Masculinity. New York: Oxford University Press.

Pazos, María (2010), "El papel de la igualdad de género en el cambio a un modelo productivo sostenible”, Revista Principios, 17, 77-102.

Rodríguez, Juan Antonio (2011), "Políticas de igualdad en un mundo de hombres: ¿una necesidad para el cambio?”, Prisma Social, 7, 1-30.

Szil, Péter (2000), "Masculinidad y paternidad: del poder al cuidado", Jornadas Internacionales a(s) Retórica(s) de la Masculinidad. Accessed on 19.09.2016, at http://www.lazoblanco.org/wp-content/uploads/2013/08manual/bibliog/material_ paternidades_0048.pdf. 
Tarrés, María Luisa (2012), “A propósito de la categoría género: leer a Joan Scott”, Sociedade e Cultura, 15(2), 379-391.

Tobío, Constanza (2012), "Cuidado e identidad de género. De las madres que trabajan a los hombres que cuidan”, Revista Internacional de Sociología, 70(2), 399-422.

Torn, Teresa (2004), "Las políticas de tiempo: un reto para las Políticas del Estado de Bienestar", Trabajo, 13, 145-164.

Valcárcel, Amelia (2008), Feminismo en el mundo global. Madrid: Ediciones Cátedra.

Valdés, Teresa; Olavarría, José (eds.) (1997), “Masculinidad/es: poder y crisis”, Ediciones de las Mujeres, no. 24.

Valles, Miguel (2005), "Metodología y tecnología cualitativas: actualización de un debate, desde la mirada más atenta en la obra de Barney Glaser", EMPIRIA: Revista de Metodología de Ciencias Sociales, 9, 145-168.

Varela, Nuria (2008), Feminismo para principiantes. Barcelona: Ediciones B.

Verdú, Vicente (2003), El estilo del mundo. Barcelona: Editorial Anagrama.

Vicent, Mary (2006), "La reafirmación de la masculinidad en la cruzada franquista", Cuadernos de Historia Contemporánea, 28, 135-151.

Waisblat, Alfredo; Sáenz, Ana (2011), "La construcción socio-histórica de la existencia. Patriarcado, capitalismo y desigualdades instaladas", Revista Sexología y Sociedad, 19(2), 172-194. Accessed on 08.10.2016, at http://revsexologiaysociedad.sld.cu/ index.php/sexologiaysociedad/article/view/195.

Received on 11.07.2017

Accepted for publication on 07.12 .2018

\section{Juan Antonio Rodríguez-del-Pino}

Facultat de Ciències Socials, Universitat de València

Campus dels Tarongers, Av. Dels Tarongers, s/n, 46021 Valencia, España

Contact: juan.rodriguez@uv.es

ORCID: https://orcid.org/0000-0002-2585-741X 


\section{Uma despedida do macho ibérico espanhol? Uma análise da masculinidade em Espanha. Conversas com especialistas}

$\mathrm{O}$ modelo tradicional de masculinidade em Espanha (o chamado macho espanhol) é o resultado de uma longa tradição para entender a maneira como a masculinidade é retratada como um modelo omnipotente que assume que "um homem tem licença para fazer tudo o que quer". Este padrão de comportamento idealizado está a mudar lentamente em Espanha, acompanhando as transformações na sociedade espanhola. Certas medidas públicas impulsionaram uma mudança na abordagem da questão de género, no geral, e da violência de género, em particular. No âmbito de uma pesquisa realizada na Universidade de Valência - entre 2013 e 2015 - entrevistaram-se especialistas e ativistas de uma associação de homens que procuram a igualdade entre homens e mulheres, numa tentativa de analisar a situação atual e, acima de tudo, examinar o futuro da masculinidade em Espanha relativamente aos avanços feitos em prol do feminismo. Tendo por base as opiniões de vários atores, certas questões surgem e as dificuldades enfrentadas por este processo são reveladas: é possível romper com os modelos tradicionais? Qual é o estado atual da coexistência entre a abordagem mais tradicional e a mais igualitária?

Palavras-chave: Espanha; igualdade de género; masculinidade; violência de género.

\section{Un adieu au macho espagnol ibérique? Une analyse de la masculinité en Espagne. Échanges avec des experts}

Le modèle traditionnel de masculinité en Espagne (le soi-disant macho espagnol) est l'héritier d'une longue tradition qui consiste à comprendre comment la masculinité est définie comme un modèle tout-puissant et qui suppose que "un homme est autorisé à faire tout ce qu'il veut". Ce modèle comportemental idéalisé est en train de changer lentement en Espagne, car il accompagne les transformations de la société espagnole. Certaines politiques publiques ont donné un élan à un changement de la manière dont on aborde la question du genre, en général, et de la violence de genre, en particulier. Dans le cadre d'une étude menée sous les auspices de l'Université de Valence, entre 2013 et 2015, des interviews ont été faites à des experts et des activistes d'une association d'hommes qui lutte pour l'égalité entre les hommes et les femmes dans le but d'analyser la situation actuelle et, surtout, d'examiner l'avenir de la masculinité en Espagne en ce qui concerne les bénéfices en faveur du féminisme. En prenant pour base les avis de plusieurs acteurs, certaines questions se posent et les difficultés auxquelles ce processus est confronté sont dévoilées: une rupture avec les modèles traditionnels est-elle possible? Quel est l'état actuel de la coexistence entre les approches les plus traditionnelles et les plus égalitaires?

Mots-clés: égalité de genre; Espagne; masculinité; violence de genre. 